\title{
IMPROVING GRAMMAR SKILL USING EGRA TECHNIQUE FOR THE STUDENTS' EIGHTH GRADE AT SMPN 5 CIMAHI
}

\author{
Mayang Kusumastuti ${ }^{1}$, Mega Pratiwi ${ }^{2}$, Hendra Husnussalam ${ }^{3}$ \\ ${ }^{1}$ IKIP Siliwangi \\ ${ }^{2}$ IKIP Siliwangi \\ ${ }^{3}$ IKIP Siliwangi \\ ${ }^{1}$ mayangksm@gmail.com, ${ }^{2}$ pratiwim397@gmail.com, ${ }^{3}$ hendrahusnussalam@ikipsiliwangi.ac.id
}

\begin{abstract}
Grammar is one part to improve four skills that we also known. To enhance grammar skill we have to prefer the accurately method as a way in studying grammar. The researcher was chosen Exposure, Generalization, Reinforcement, and Application (EGRA) technique as a method to teaching English grammar to students' eigtht grade at SMPN 5 Cimahi. It was arranged with using pre-experimental method, peculiarly one-group pre-test post-test design. The technique showed that can develop grammar skill students'. The average score of the test result is 40,83 for the pre-test and 71,70 for the post-test. From the result, it can determine that EGRA technique can improve grammar skill students'. Besides that, EGRA technique can build a good team work in the classroom.
\end{abstract}

Keywords: Grammar, Present Continuous Tense, EGRA Technique

\section{INTRODUCTION}

English becomes international language to unite the world. In the era of globalization, learning English is very important because English able for linking and make easily people in the most of countries are communicated each other based on the development in the field of economic, business, education and also politic, Parmawati (2018). It applies to interact each other, peculiarly with the foreigners. In building a good communication we should understand the rules of the way to interact. To attain that goal we necessary to dominate some prevalent skills as listening, speaking, reading, and writing. In addition those skills we must master spelling, pronunciation, vocabulary, and grammar as the basis for accomplishing each skill.

Prior to mastering four skills, the students' have to master the rules in using English language. The rules in language are called grammar. Grammar is the highest important thing in all skills because it has a role as a root to development our skills. According to Haussamen, Benjamin, Kolln, \& Wheeler (2003) grammar is the skunk at the garden party of the language arts. It means that grammar is an art for that language itself. It is supported by Ismail (2010, as cited in Apsari, 2018) that grammar plays a significant role in communication since it shows how language is used.

For the students' Junior High School level, learning English grammar will be more difficult to learn. In particular learning tenses, due to it has varieties of them. Besides the material, the way to deliver the lesson very extremely in influencing how the students' can learn and understand the lesson. 
To increase students' understanding about grammar, the teachers can adoption group discussion with EGRA technique in the classroom. Students' will try to exchange the ideas each other with their group. So, they can explain the material with their own way. Otherwise, the teacher can know how they can understand with the type of the tenses.

Teacher can be a facilitator to guide the students' confidence to dispense the ideas each other. The technique can decide the problem in addition a new understanding about grammar as a subject. Teacher also has a role to justify the grammar properly, if the students' are already intimate with the kinds of the tenses they can.

The method in teaching English has an essential aspect to deliver the material. Learning approaches are very influential in conducting material. If the method is easy to be understood, it can help students enjoying the learning process. Also can make students' think that learning English grammar is not difficult as they think before.

To make this study approve, the researcher was chosen the Exposure, Generalization, Reinforcement, Application (EGRA) technique as a method in teaching English grammar. To identify the progress of the research, the researcher used pre-experimental with one-group pretest post-test design, which the first process is giving the pre test to perceive the ability of the students', then give a treatment about the research, and for the final process is giving the post test to determine how much the EGRA technique be able to develop grammar skill students'.

Based on the problem of the research, it could be defined as follow; Can EGRA technique improve grammar skill of the students' eighth grade of Junior High School 5 Cimahi?

\section{Hypothesis}

1. Alternative Hypothesis (Ha) means there is Exposure, Generalization, Reinforcement, and Application (EGRA) technique can improve grammar skill students'.

2. Null Hypothesis (H0) means there is Exposure, Generalization, Reinforcement, and Application (EGRA) technique cannot improve grammar skill students'.

\section{Grammar}

Grammar is a rule to create a sentence, it can influence the way of communication can be delivered and received. It is supported by Argawati (2017) that in conclusion, grammar is a rule of language which has conventional arrangement to make sentences and convey larger meaning. Some of them are tenses, passive voice, sentences, parts of speech, conditional sentences, and many more.

According to Kolln \& Funk (2009) grammar is certainly a common word. Such as stated by Ingemann \& Crystal (2008) grammar is seen as an inherently meaningful (or 'symbolic') component of the theory, linking semantics (viewed in conceptualist terms) and phonology. grammar is a set of formal rules which projects a finite set of sentences upon the potentially infinite set of sentences that constitute the language as a whole, and it does this in an explicit manner, assigning to each a set of structural descriptions.

Farisatma, Nasmilah, \& Rahman (2017) stated grammar is one of the English language elements which is very important to be mastered in all skill of language such as speaking, reading, and writing. That opinion is also disclosed by Haryudin \& Argawati (2018) that stated grammar covers many themes that may confuse students' on memorizing and understanding them. 
From the experts above, the researcher can achieve that grammar has a substancial aspect in mastering each skills. Besides, it has a few parts. Every element of grammar has their own function in the sentence. One element of the grammar named tenses. Tenses are pattern or a structure language to be a sentence that refers to the time of occurance. Tenses has sixteen parts, in which each tenses effected by the time of the occurance. That also give an affect to the sentence, we can realize what the meaning of the sentence from knowing when it happen.

\section{Present Continuous Tense}

Michaelis Laura (2006) said, when describing the meanings of the tenses, linguists have relied on a specific instance of the space-time analogy: the timeline. The timeline is a line (or, equivalently, an ordered set of points) that is unbounded at both ends and segmented into three parts: the past, the present, and the future. The points on the timeline may be times by themselves or times paired with events. While we can describe various relations among points on the timeline, only one type of relation counts as a tense relation: that which includes the time at which the linguistic act is occurring.

As reported by Ansell (2000) in English, the Present Continuous tense is usually used to express continuing, ongoing, actions which are taking place at the moment of speaking or writing. While Eastwood (2002) said that we use the present continuous for a present action over a period of time, something that we are in the middle of now. Stand on Thomson, Martinet, \& Draycott (1986) the present continuous tense is formed with the present tense of the auxiliary verb be + the present participle.

\section{EGRA Technique}

Exposure, Generalization, Reinforcement, and Application (EGRA) according to Marpudin (2008, as cited in Nurrahmatiah (2010).

1. Exposure is the teacher giving leading question to the students' about the lesson that will be taught such as (picture show, brain storming, and giving key word).

2. Generalization are such as:

a. Teacher asks to the students' to make a group at least 4-5 students for each group.

b. Teacher gives a task such as text, question, quiz that the point must be guiding the students to find the function, and the form to build up the sentence that has been taught.

c. Teacher asks the students' to discuss about the answer in the group.

d. The teacher writes down the answer in the white board.

e. The teacher gives praise (appreciation) what the students' have done.

f. The teacher gives example how to pronounce the answer in the white board.

3. Reinforcement:

a. The teacher explains back some students' answers in the white board.

b. The teacher gives explanation as reinforcement about the function and the structural form that has been thought.

c. The teacher gives example as a model.

d. The gives drill continuously about the pronunciation.

e. The teacher gives reinforcement back by giving task and question to the students'.

f. The teacher ask the students' to the task with their couple.

g. The teacher discusses about the answer with their couple.

h. The students' discuss the answer classically with their teacher. 
4. Application is the students do the task individually, the teacher gives task card to the students about situation and cases, the students are asked to make some their own answer to respond the situation and cases that it has been given and the teacher gives homework for explaining in the next meeting.

\section{METHOD}

The researcher conducted pre-experimental as a research design. Refers to Creswell (2009) with pre-experimental designs, the researcher studies a single group and provides an intervention during the experiment. Ary, Jacobs, \& Sorensen (2010) stated preexperimental designs do not have random assignment of subjects to groups or other strategies to control extraneous variables. It has three kinds of pre-experimental; they are one shot case study, one-group pre-test post-test design, and static group comparison. As a guide to carry out the research, the researcher used the one-group pretest-posttest design.

As stated in Ary, Jacobs, \& Sorensen (2010) the one-group pretest-posttest design usually involves three steps: (1) administering a pretest measuring the dependent variable; (2) applying the experimental treatment $X$ to the subjects; and (3) administering a post test, again measuring the dependent variable. Differences attributed to application of the experimental treatment are then evaluated by comparing the pretest and posttest scores.

Table 1. Figure of One-Group Pretest-Posttest Design

\begin{tabular}{ccc}
\hline Pretest & Independent & Posttest \\
\hline$Y_{1}$ & $\mathrm{X}$ & $Y_{2}$ \\
\hline
\end{tabular}

Note:

$Y_{1}$ process is the begin of the research to take a pre test.

$\mathrm{X}$ process is giving a treatment.

$Y_{2}$ process is the last process with take a post a test.

The population of this research is eighth grade students of Junior High School 5 Cimahi in the academic year 2019/2020 as population. For the sample of the population, the researcher taken class $8 \mathrm{H}$ with total sample is 30 students.

To complete the research, the researcher collected the data by taking pre test and post test. Pre test was tested to recognize the students' ability of grammar before the treatment. Afterwards, the researcher did some treatments use Exposure, Generalization, Reinforcement, and Application (EGRA) technique as a method to improve grammar skill students'. And the curtains step is taking post test to confirm the treatment progress. The data collected were analyzed by adopting SPSS 17 and construed the result of the research.

\section{RESULTS AND DISCUSSION}

\section{Results}

The data collected has been calculated by SPSS 17, the conclusion of the data shown below.

Table 1. The normality test 
One-Sample Kolmogorov-Smirnov Test

\begin{tabular}{|ll|r|r|}
\hline & & \multicolumn{1}{|c|}{ Pretest } & \multicolumn{1}{c|}{ posttest } \\
\hline N & & 30 & 30 \\
Normal & Mean & 40.83 & 71.70 \\
Parameters ${ }^{\text {a,b }}$ & Std. Deviation & 6.000 & 16.781 \\
Most Extreme & Absolute & .174 & .112 \\
Differences & Positive & .110 & .088 \\
& Negative & -.174 & -.112 \\
Kolmogorov-Smirnov Z & .955 & .611 \\
Asymp. Sig. (2-tailed) & .322 & .850 \\
\hline
\end{tabular}

a. Test distribution is Normal.

b. Calculated from data.

From the result above, the mean of the pre test was 40,83 with the Asymp.sig (two -tailed) of the pre test was .322 and the mean of the post test was 71,70 with the Asymp.sig (two -tailed) of the pre test was .850. If the Asymp.sig (two -tailed) $>0,05$ the data distributed normally and if the Asymp.sig (two -tailed) $<0,05$ the data not distributed normally. From the result of data pre test and post test it showed that the data distributed normally.

Table 2. Compare mean two sample test

Paired Samples Test

\begin{tabular}{|c|c|c|c|c|c|c|c|c|c|}
\hline & & \multicolumn{5}{|c|}{ Paired Differences } & \multirow[b]{3}{*}{$t$} & \multirow[b]{3}{*}{ df } & \multirow{3}{*}{$\begin{array}{l}\text { Sig. (2- } \\
\text { tailed) }\end{array}$} \\
\hline & & \multirow[b]{2}{*}{ Mean } & \multirow{2}{*}{$\begin{array}{c}\text { Std. } \\
\text { Deviation }\end{array}$} & \multirow{2}{*}{$\begin{array}{c}\text { Std. Error } \\
\text { Mean }\end{array}$} & \multicolumn{2}{|c|}{$\begin{array}{c}95 \% \text { Confidence Interval } \\
\text { of the Difference }\end{array}$} & & & \\
\hline & & & & & Lower & Upper & & & \\
\hline Pair 1 & $\begin{array}{l}\text { pretest - } \\
\text { posttest }\end{array}$ & -30.867 & 14.026 & 2.561 & -36.104 & $-2.563 \mathrm{E} 1$ & -12.053 & 29 & .000 \\
\hline
\end{tabular}

From the result above, the data showed that Asymp.sig (two -tailed) was .000, with the level of significance level was .05. The result of significance was .000 and $<0,05$ it means the result was lower than the significance level. From the data above, we can deduce that the null hypothesis was refused and the alternative hypothesis was received. In kind, the aftereffect of Exposure, Generalization, Reinforcement, and Application (EGRA) technique showed that the technique can improve grammar skill students'.

\section{Discussion}

Depend on the data above the researcher was held with pre-experimental design one-group pretest-posttest design. For the practice of the research, the researcher was conducted pre test, treatment for two meetings, and the curtains is post test. Thus, to make this research, the researcher needs four meetings to complete the data analysis.

The research was obtained the result. It was showed that Exposure, Generalization, Reinforcement, and Application (EGRA) technique can increase students' understanding about grammar, specifically about Present Continuous Tense. It was proven with the average score on the pre test is 40,83 and the average score on the post test is 71,70 .

From the data collected and data analyzed we can achieve that Exposure, Generalization, Reinforcement, and Application (EGRA) technique can improve students' grammar skill. 
Additionally, the technique can be used as a tool to make teaching and learning more variable in the classroom.

\section{CONCLUSION}

Depend on the result and discussion, it can be concluded that application of Exposure, Generalization, Reinforcement, and Application (EGRA) technique can help students' to find their own way in learning English grammar, exclusively in learning Present Continuous Tense. Besides that, Exposure, Generalization, Reinforcement, and Application (EGRA) technique help students' in building a good team work to finish the excercise and divisible their knowledge and the information about the lesson. The technique can also help the teacher to give a chance the students to discuss each other. Thus the teacher has a role to guide and observe the students.

From the outcome, the data showed the score before treatment and after treatment showed significant difference with the average score of the pre test is 40,83 and the average score of post test is 71,70 . Significant result from the data showed .000 with the level significant .05 , thus the conclusion of the data outcome was lower than level significance. It means the null hypothesis was refused and the alternative hypothesis was received. Therefore, apply Exposure, Generalization, Reinforcement, and Application (EGRA) technique as a method in teaching in the classroom can improve grammar skill for students.

\section{ACKNOWLEDGMENTS}

We would like to express our deep gratitude to Allah SWT that has given us convenience, health, and strength to finish our project. We would like offer our very great appreciation to Hendra Husnussalam, M.Pd and Aseptiana Parmawati, M.Pd as our advisor journal, in guiding us to finish the project, and provided us with very valuable. We expect our research in this journal can help the other researcher to complete the other research and also can be used by the teacher to teach in the classroom. Definitely, thanks to Headmaster, Head of Curriculum, English Teacher, and The Students of Junior High School 5 Cimahi to give us a chance take a research and provide us a facility during the research. Additionally to our beloved friends to help us complete the research.

\section{REFERENCES}

Ansell, M. (2000). Free English Grammar. Turkey: SeyfiHoca.

Apsari, Y. (2018). Snowball Throwing in Teaching Grammar. Lingual, 10(1), 52-59.

Argawati, N. O. (2017). Think-Pair-Share: Its Implementation To Improve Students' Capability On Understanding Grammar On The Second Semester Students Of Stkip Siliwangi. Journal Of English Pedagogy, Linguistics, Literature, And Teaching, 5(1).

ARY, D., JACOBS, L. C., \& SORENSEN, C. (2010). Introduction to Research in Education (Eight edit). Canada: Wadsworth, Cengage Learning.

CRESWELL, J. W. (2009). RESEARCH DESIGN Qualitative, Quantitative and Mixed Methods Approaches. In Muqarnas (Third Edit). https://doi.org/10.2307/1523157

Eastwood, J. (2002). Oxford guide to english. https://doi.org/10.1017/CBO9781107415324.004 Farisatma, Nasmilah, \& Rahman, F. (2017). Applying Group Work to Improve Student' s Grammar Achievements. 3(5), 1971-1975.

Haryudin, A., \& Argawati, N. O. (2018). Lesson Study To Improve Student English Grammar Mastery Using Jigsaw Technique To the. Indonesian EFL Journal, 4(January). https://doi.org/10.25134/ieflj.v4i1.798.Received 
Haussamen, B., Benjamin, A., Kolln, M., \& Rebecca S Wheeler. (2003). Grammar Alive! A GUIDE FOR TEACHERS. United States: National Council of Teachers of English.

Ingemann, F., \& Crystal, D. (2008). Dictionary of Linguistics and Phonetics. In Language (Sixth Edit). https://doi.org/10.2307/417640

Kolln, M., \& Funk, R. (2009). Understanding English Grammar (Ninth Edit). Boston Columbus Indianapolis New York San Francisco Upper Saddle River Amsterdam Cape Town Dubai London Madrid Milan Munich Paris Montreal Toronto Delhi Mexico City Sao Paulo Sydney Hong Kong Seoul Singapore Taipei Tokyo: Pearson.

Michaelis Laura. (2006). The Handbook Of English Linguistics. Singapore: Blackwell Publishing.

Nurrahmatiah. (2010). Improving The Students' Grammar Ability Through Egra (Exposure, Generalization, Reinforcement, Application) Method Of The Second Year Students Of Smp Moncoloe Makassar (Vol. 9). Uin Alauddin Makassar.

Parmawati, A. (2018). Using Analytic Teams Technique To Improve Students'speaking Skill. Edulitics (Education, Literature, And Linguistics) Journal, 3(2), 21-25.

Thomson, A., Martinet, A., \& Draycott, E. (1986). A Practical English Grammar. Oxford University Press, 332. Retrieved from ftp://119246239157.ctinets.com/education/Oxford University Press - A Practical English Grammar.pdf 